\title{
CAPítTULO 7
}

\section{INDUSTRIALIZAÇÃO RECENTE E DINÂMICA LOCACIONAL DAS INDÚSTRIAS NA CIDADE PEQUENA DE EXTREMA (MG)}

Elias Mendes Oliveira

\section{INTRODUÇ̃̃O}

As cidades pequenas constituem uma particularidade do fenômeno urbano, fruto do desenvolvimento desigual e combinado do território sob o capitalismo (SPOSITO; SILVA, 2013). Estas cidades apresentam menor complexidade demográfica, morfológica e funcional do que as metrópoles, as cidades grandes e as cidades médias, e compõem um conjunto heterogêneo de lugares, resultante das múltiplas temporalidades e espacialidades de apropriação do território (FRESCA, 2001).

Tradicionalmente concebidas como últimos elos na confluência do urbano e do rural (CORRÊA, 2011), a dinâmica socioespacial nas cidades pequenas frequentemente encontra-se associada às atividades agrícolas. Ainda que não seja excepcionalidade entre as cidades pequenas (FRESCA, 2001), o uso industrial do território normalmente se caracteriza pela incipiência - micro e pequenos estabelecimentos, de ramos tradicionais, mantidos por capitais locais ou regionais e com áreas de mercado restritas - ou pela integração com atividades agrícolas, como é o caso das agroindústrias. 
Comumente, as cidades pequenas são preteridas pelo grande capital da indústria. Em geral, os grandes investimentos do setor secundário são direcionados aos centros que ocupam as posições superiores da hierarquia urbana, em tese, lugares melhor equipados para abrigar as fábricas e cujo volume de economias de aglomeração contribui para a reprodução ampliada do capital.

No entanto, algumas cidades pequenas no Brasil tornaram-se destinos preferenciais para o grande capital da indústria recentemente, contrariando os estudos clássicos em Geografia Industrial, que enfatizavam a relação positiva entre industrialização e tamanho urbano (PORCARO, 1977). A implantação de grandes fábricas nessas cidades evidencia a complexidade crescente da organização e das relações industriais sob os efeitos da internacionalização do capital e da produção, da reestruturação produtiva das empresas e da globalização econômica, em escala global, e da desconcentração industrial e da guerra fiscal dos lugares, em escala regional.

Com o propósito de contribuir com a reflexão sobre as mudanças na dinâmica locacional das indústrias e seus impactos sobre a divisão territorial do trabalho no Brasil, o presente capítulo ${ }^{1}$ aborda a industrialização em Extrema (MG), processo alavancado, em meados da década de 1990, pela de introdução de grandes indústrias, nacionais ou estrangeiras, nesta cidade pequena. As análises a seguir objetivam: a) avaliar os processos, em curso nas escalas global e regional, responsáveis pelo aprofundamento da divisão territorial do trabalho da indústria no sentido de algumas cidades pequenas brasileiras; b) examinar os fatores locacionais, presentes no território, que atraíram o grande capital da indústria à cidade; c) analisar como atuam os agentes sociais diretamente ligados ao atual ciclo de crescimento industrial, econômico e urbano no município. Em última instância, esta abordagem visa compreender os papéis desempenhados por Extrema no atual cenário do espaço e das relações industriais no Brasil.

Este capítulo sintetiza parte das discussões contidas na tese "A implantação de grandes indústrias de capitais nacionais e internacionais na cidade pequena de Extrema (MG): processos, fatores e agentes" (OLIVEIRA, 2018), desenvolvida entre 2015 e 2018, no Programa de Pós-Graduação em Geografia (Organização do Espaço), da Universidade Estadual Paulista Júlio de Mesquita Filho (Unesp), campus Rio Claro (SP), sob a orientação do Prof. Dr. Auro Aparecido Mendes. 


\section{DINÂMICA LOCACIONAL DAS INDÚSTRIAS E CIDADES PEQUENAS NO BRASIL}

A compreensão das mudanças nos padrões de localização industrial deve basear-se na abordagem multiescalar dos processos que influenciam a distribuição espacial das unidades fabris, porque:

a) os processos dinamizam o território e distinguem-se quanto à escala de origem e à escala de realização, revelando os diferenciais de poder entre os agentes sociais que participam do processo produtivo (SANTOS, 2001);

b) a articulação única dos processos, ao nível dos lugares, permite explicar as razões pelas quais algumas localidades, como algumas cidades pequenas, se tornaram, recentemente, destinos das grandes inversões de capital da indústria.

Historicamente, as unidades fabris e os investimentos das indústrias são direcionados aos lugares cujas características físicas e sociais contribuam para reduzir os custos de produção e elevar a competitividade das empresas. $\mathrm{Na}$ medida em que os lugares são únicos e oferecem possibilidades distintas para a valorização do capital (SANTOS, 2001), cada localidade integra-se de forma diferenciada aos processos que dinamizam, das diferentes escalas geográficas, o espaço industrial. Cabe, pois, discutir brevemente os processos cuja vigência vem alterando os padrões de localização da indústria no território brasileiro.

Na escala global, a internacionalização do capital e da produção surgiu como resposta dos agentes hegemônicos - transnacionais e seus aliados no aparelho estatal - para conter a desvalorização cíclica do capital nos países centrais. De acordo com Harvey (2005), a desvalorização decorre dos mecanismos de concentração e de centralização do capital, intrínsecos ao capitalismo, e manifesta-se sob a forma de superacumulação de capital e/ou de força de trabalho.

De acordo com Mendes (1997) e Selingardi-Sampaio (2009), a internacionalização do capital e da produção favorece o acesso aos recursos naturais, à mão de obra abundante e barata e ao mercado consumidor expressivo de alguns países da periferia capitalista. Da mesma forma, permite usufruir os incentivos desonerações fiscais, créditos, dotação de infraestrutura etc. - concedidos pelos governos desses países às indústrias, rebaixando os custos da produção.

Assim sendo, a internacionalização do capital e da produção consiste em uma estratégia para a exploração de vantagens locacionais em lugares diferentes do país de origem do capital, ampliando os horizontes para a acumulação capita- 
lista e o gerenciamento dos insumos, do mercado consumidor e do trabalho, em escala global (SPOSITO; SANTOS, 2012).

Embora não seja recente na história do capitalismo, a internacionalização do capital e da produção adquiriu novo dinamismo na década de 1970, consoante a uma série de transformações técnico-organizacionais que permitiram às grandes corporações segmentar a produção e empregar uma lógica multiterritorial, relativizando os efeitos da distância nas operações industriais (MENDES, 1997; SPOSITO; SANTOS, 2012).

No bojo da reestruturação produtiva das empresas e da globalização, as novas formas de organização e de racionalização da produção estimularam a disjunção espacial dos estabelecimentos industriais (MENDES, 1997). Por sua vez, o sistema de produção industrial, dividido entre diversos lugares, foi assegurado pela modernização e pela disseminação de redes de circulação (transportes, telecomunicações e energia), que conferiram maior fluidez ao território e redimensionaram o peso dos fatores locacionais nas diversas etapas do processo produtivo (MENDES, 1997; SELINGARDI-SAMPAIO, 2009).

Em consequência, as empresas passaram a se estruturar em redes e os circuitos espaciais de produção expandiram-se pelo território, integrando várias cidades, regiões e países ao processo produtivo. Por outro lado, o comando da produção concentrou-se em alguns centros de gestão do território (como algumas metrópoles e cidades grandes), a partir dos quais os agentes hegemônicos coordenam os círculos de cooperação responsáveis pela circulação de capitais, informações e ordens entre os lugares que participam da produção.

$\mathrm{Na}$ escala regional, verifica-se o fortalecimento da desconcentração espacial da indústria no Brasil. Este processo, que teve início na década de 1960, intensificou-se em 1970, basicamente pela presença de fatores repulsivos à localização industrial nos grandes centros e de fatores de atração no interior do país (MENDES, 1997; SELINGARDI-SAMPAIO, 2009).

As deseconomias de aglomeração começaram a ocorrer nas regiões metropolitanas devido à elevação dos preços do solo urbano, às dificuldades logísticas, aos altos custos para modernização de fábricas antigas, à sindicalização da mão de obra, aos conflitos de vizinhança resultantes das operações industriais etc. $\mathrm{Na}$ prática, as deseconomias de aglomeração originaram forças centrífugas sobre os estabelecimentos consolidados nos grandes conjuntos urbanos e sobre os novos investimentos da indústria, incitando-os a buscar localizações mais favoráveis no território. 
Os fatores de atração, por sua vez, estão relacionados à disseminação das condições gerais de produção no território desde a década de 1960, fruto das ações do Estado para modernizar o país, como a implantação dos sistemas técnicos de apoio à produção, as políticas de substituição de importações e a criação de indústrias de base.

Os estados e os municípios também passaram a fomentar a industrialização por meio de políticas próprias para atrair os estabelecimentos que migravam das metrópoles ou os novos investimentos estrangeiros na produção. As principais alternativas utilizadas nessas políticas foram a concessão de incentivos fiscais e creditícios e a doação de terrenos às empresas, além da provisão de benfeitorias ligadas à infraestrutura, principalmente nos distritos industriais.

No contexto da globalização neoliberal, a partir da década de 1990, a disputa entre os entes subnacionais para atrair os investimentos industriais intensificou-se, configurando a guerra fiscal dos lugares (SANTOS, 2001). Este processo, que se caracteriza pela criação de condições artificiais de atração da indústria em lugares com menor tradição no setor secundário, basicamente por meio de renúncias fiscais (SANTOS, 2001; SELINGARDI-SAMPAIO, 2009), contribuiu para que muitas cidades pequenas competissem pelos capitais da indústria, em circulação nas escalas global e regional, com as metrópoles, cidades grandes e cidades médias.

Contudo, a industrialização em cidades médias e pequenas, baseada sobretudo nas etapas da produção propriamente dita (beneficiamento e montagem industrial), não foi capaz de eliminar as assimetrias que, historicamente, caracterizam o espaço industrial brasileiro. Na realidade, a desconcentração industrial vem promovendo a reestruturação da divisão territorial do trabalho da indústria e redefinindo as hierarquias entre os lugares envolvidos na produção sob o comando da metrópole paulistana, que concentra a sede das principais empresas, bancos e instituições públicas do país (MENDES, 1997; SELINGARDI-SAMPAIO, 2009).

Em perspectiva multiescalar, sob a influência dos processos descritos anteriormente, pode-se afirmar que áreas tradicionalmente industrializadas vêm perdendo sua capacidade de atração e de sustentação de estabelecimentos industriais, os quais são direcionados para áreas mais atrativas, deixando naquelas localidades problemas como o desemprego, a formação de brownfields, a redução da arrecadação municipal e seu consequente repasse para as políticas públicas de conotação social, entre outros. 
Por sua vez, as cidades que passaram a acolher novos investimentos industriais integraram redes de produção mais amplas, cujas lógicas produtivas extrapolam as escalas local e regional e são ditadas a distância por agentes sociais que operam nas escalas nacional ou global. Nesses lugares, potencializa-se a demanda sobre o solo urbano e intensificam-se os fluxos materiais e imateriais pelo território, tornando mais complexo e dinâmico o processo de produção do espaço geográfico, como é o caso de algumas cidades pequenas brasileiras.

Obviamente, não são todas as cidades pequenas brasileiras que dispõem dos fatores locacionais para a atração de grandes investimentos da indústria, nos dias atuais. Destarte, existe um número reduzido de cidades pequenas que dispõem das condições gerais de produção capazes de integrá-las aos circuitos espaciais de produção e aos círculos de cooperação de grandes indústrias. Em sua maioria, estas cidades localizam-se no Centro-Sul e dispõem de posição geográfica estratégica em relação aos principais centros urbano-industriais e corredores logísticos do país, além de mão de obra mais barata que nos grandes centros urbanos, como é o caso de Extrema, objeto de estudo deste capítulo.

\section{INDUSTRIALIZAÇÃO RECENTE E ESPAÇO INDUSTRIAL EM EXTREMA}

$\mathrm{O}$ uso industrial do território em Extrema tornou-se mais complexo na medida em que o município foi incorporado aos processos que condicionam a dinâmica locacional das indústrias em diferentes escalas geográficas.

Até o início da década de 1970, o espaço industrial em Extrema caracterizava-se pela presença de micro e pequenos estabelecimentos, de gêneros tradicionais, com organização familiar e mantidos por capitais locais ou regionais. Operando em condições arcaicas de transformação industrial, as pequenas indústrias beneficiavam insumos agrícolas produzidos na zona rural e comercializavam suas mercadorias no próprio município. A dinâmica socioespacial estava associada basicamente às atividades no campo, com destaque para a cafeicultura, as quais geravam a maior parte das receitas locais e condicionavam o predomínio da população rural sobre a urbana. A indústria aparecia como atividade complementar, portanto, com pouca capacidade de dinamizar a economia e o território.

O caráter incipiente da industrialização em Extrema, naquele momento, era condizente com o padrão concentrado da localização industrial nas cidades grandes e com os papéis geralmente desempenhados pelas cidades pequenas na rede urbana brasileira, ou seja, como lugares centrais na transição urbano-rural (CORRÊA, 2011). 
O período entre 1970 e meados dos anos 1990 assinalou o ingresso de capitais nacionais da indústria em Extrema, no contexto da desconcentração industrial no Brasil. A introdução de capitais externos da indústria em Extrema foi motivada, sobretudo, pela posição geográfica estratégica do município no território nacional - entre dois importantes centros urbano-industriais (São Paulo e Belo Horizonte) após a conclusão das obras da Rodovia Fernão Dias (BR 381), em 1961.

A implantação da BR 381 constituiu um marco na dinâmica socioespacial em Extrema porque assegurou a fluidez territorial responsável por intensificar as interações espaciais do município com a capital e o interior paulista, conferindo novas funções à cidade pequena na divisão territorial do trabalho (local de segunda residência, de uso turístico e de uso industrial). A implantação de indústrias paulistanas repercutiu no mercado de trabalho e na estrutura produtiva local, elevando a participação do setor secundário na economia e promovendo novas dinâmicas socioespaciais no território, como a diversificação econômica, o crescimento demográfico e o aumento das taxas de urbanização.

No entanto, Extrema ainda não constituía destino prioritário para o grande capital da indústria, que era direcionado principalmente às cidades médias que disponibilizavam economias de aglomeração capazes de assegurar maior rentabilidade ao capital. No contexto microrregional, Pouso Alegre (MG) concentrou a maior parte dos investimentos externos da indústria, de modo que não havia tanta discrepância entre as cidades pequenas da rede urbana, como se observaria nos anos posteriores.

O período entre 1996 e 2018 foi marcado pelos grandes investimentos nacionais e estrangeiros da indústria de transformação em Extrema, os quais expandiram e diversificaram sobremaneira o parque industrial no município. $\mathrm{O}$ grande salto quantitativo e qualitativo na industrialização local está relacionado, principalmente, aos efeitos da duplicação da BR-381 e das políticas de industrialização empreendidas pelo governo estadual e municipal no contexto da globalização neoliberal e da guerra fiscal dos lugares, os quais convergiram para acentuar a desconcentração industrial no sentido do Sul e Sudoeste de Minas Gerais e do município de Extrema, em particular.

Atualmente, o parque industrial em Extrema é composto majoritariamente por estabelecimentos de micro e pequeno porte, de capitais locais ou não, criados nas três últimas décadas. Dados recentes da Prefeitura Municipal de Extrema (2017b) contabilizaram 255 estabelecimentos em 2017.

Em geral, estes estabelecimentos caracterizam-se pelo ciclo de vida curto, típico das indústrias de tamanho reduzido, de gêneros tradicionais, de 
organização familiar e que exploram áreas de mercado restritas. Os principais fatores que explicam o encerramento precoce das funções produtivas entre as pequenas indústrias são: a maior suscetibilidade à competição intercapitalista e aos cenários macroeconômicos desfavoráveis, a incapacidade administrativa, a obsolescência das técnicas e das unidades fabris, o baixo grau de capitalização e de domínio tecnológico das empresas.

A participação da indústria extrativa em Extrema é mínima, tanto no número de estabelecimentos quanto na geração de postos de trabalho; desse modo, o parque industrial é composto essencialmente por indústrias de transformação.

Em relação à economia local, o setor secundário contribuiu com 23,52\% do Produto Interno Bruto Municipal (PIB-M), em 2015, contra 0,14\%, 51,89\% e 24,45\% de participação da agropecuária, dos serviços e dos impostos, respectivamente (IBGE, 2015)2. Ainda que não seja o principal tributário das receitas locais, o Secretário de Desenvolvimento Econômico e Empreendedorismo da Prefeitura Municipal de Extrema afirma que:

\footnotetext{
o setor industrial é a principal economia do município e também o maior gerador de empregos. A industrialização impulsionou o desenvolvimento do comércio, dos serviços e também a arrecadação (que sustenta todos os programas sociais do município). O Imposto sobre Circulação de Mercadorias e Serviços (ICMS) representa metade da arrecadação do município (CARVALHO, 2018).
}

Em função do significado da atividade secundária para o mercado de trabalho, a economia e a composição das receitas municipais, é lícito qualificar Extrema como uma "cidade pequena industrial" na divisão territorial do trabalho. A concentração de estabelecimentos e de fluxos industriais no território condiciona a dinâmica socioespacial no município na medida em que impulsiona a expansão e a diversificação da capacidade produtiva, o crescimento demográfico, a urbanização, os movimentos populacionais (êxodo rural, migrações pendulares e inter-regionais), a diferenciação do espaço urbano, o acréscimo de centralidade na rede urbana e o maior alcance das interações espaciais.

A expansão e a diversificação do parque industrial em Extrema nas três últimas décadas decorrem:

2 Em números absolutos, a contribuição dos setores de atividade econômica no PIB-M (vezes 1.000) em Extrema, no ano de 2015, foi de R\$ 7.133,69, para a agropecuária; de R\$ 1.196.425,88, para a indústria; de $\mathrm{R} \$ 2.639 .489,64$, para os serviços; e de $\mathrm{R} \$ 1.243 .088,63$, para os impostos. Naquele ano, o PIB-M (vezes 1.000) de Extrema totalizou R $\$ 5.086 .137,84$ e constituiu o terceiro maior no Sul e Sudoeste de Minas Gerais, atrás de Pouso Alegre, com $\mathrm{R} \$$ 6.554.233,15, e Poços de Caldas (MG), com R\$ 6.503.681,84 (IBGE, 2015). 
a) do acúmulo das condições gerais de produção para diversos tipos de indústrias no território local, principalmente para as fases da produção propriamente dita, intensivas em trabalho e processos repetitivos, como o beneficiamento e a montagem industrial;

b) do modelo de industrialização que prioriza os grandes estabelecimentos de procedência exógena, cuja capacidade de resiliência às oscilações macroeconômicas e à concorrência intercapitalista é maior do que entre as indústrias de menor porte ou mantidas por capitais endógenos.

O Quadro 1 caracteriza os grandes estabelecimentos industriais de origem exógena em Extrema. No que se refere ao tamanho dos estabelecimentos, apenas a Pandurata Alimentos, a Multilaser, a CRM, a HBA Hutchinson e a Panasonic foram classificadas como indústrias de grande porte, segundo a tipologia proposta pelo Sebrae (2013), porque empregavam 500 ou mais funcionários em 2015/2016 (SINMEC, 2016). Os outros estabelecimentos foram considerados indústrias de médio porte, uma vez que contabilizavam entre 100 e 499 trabalhadores, no mesmo período (SINMEC, 2016).

Quanto aos gêneros industriais, o campo de atuação das grandes indústrias é diversificado e abrange a fabricação de bens intermediários para indústrias automobilísticas, de produtos alimentícios, de produtos de borracha e material plástico, de produtos e materiais eletrônicos, de produtos e materiais elétricos, de produtos de papel e celulose, de produtos de metal e metalurgia. 
Quadro 1 - Grandes indústrias de capitais exógenos em Extrema (MG) - 2015/2016.

\begin{tabular}{|c|c|c|c|c|c|}
\hline Indústria & $\begin{array}{l}\text { Início das } \\
\text { atividades }\end{array}$ & Gênero industrial & Funcionários & Tamanho & $\begin{array}{c}\text { Origem dos } \\
\text { capitais }\end{array}$ \\
\hline Pandurata Alimentos LTDA & 2004 & Produtos alimentícios & 1.500 & Grande & São Paulo \\
\hline Multilaser Industrial S/A & 2005 & Produtos eletrônicos & 1.500 & Grande & São Paulo \\
\hline $\begin{array}{c}\text { CRM Indústria e Comércio de } \\
\text { Alimentos LTDA }\end{array}$ & 2008 & Produtos alimentícios & $\mathrm{X}$ & Grande & São Paulo \\
\hline $\begin{array}{c}\text { HBA Hutchinson Brasil } \\
\text { Automotive LTDA }\end{array}$ & 1998 & $\begin{array}{l}\text { Produtos de borracha } \\
\text { e de material plástico }\end{array}$ & 750 & Grande & França \\
\hline Panasonic do Brasil LTDA & 2011 & $\begin{array}{c}\text { Produtos e materiais } \\
\text { elétricos }\end{array}$ & 600 & Grande & Japão \\
\hline $\begin{array}{c}\text { Delo Indústria e Comércio } \\
\text { LTDA }\end{array}$ & 1997 & Papel e celulose & 450 & Médio & São Paulo \\
\hline $\begin{array}{c}\text { Fagor Ederlan Brasileira } \\
\text { Autopeças LTDA } \\
\text { (Grupo Mondragón) }\end{array}$ & 2001 & Automotivo & 440 & Médio & Espanha \\
\hline $\begin{array}{c}\text { Indústria Metalúrgica Frum } \\
\text { LTDA }\end{array}$ & 1974 & Automotivo & 429 & Médio & São Paulo \\
\hline $\begin{array}{c}\text { Soft Film Indústria e } \\
\text { Comércio de Plásticos LTDA } \\
\text { (Grupo Zaraplast) }\end{array}$ & 2009 & $\begin{array}{l}\text { Produtos de borracha } \\
\text { e de material plástico }\end{array}$ & 231 & Médio & São Paulo \\
\hline $\begin{array}{l}\text { Kidde Brasil LTDA (United } \\
\text { Technologies Corporation) }\end{array}$ & 2000 & Automotivo & 200 & Médio & EUA \\
\hline $\begin{array}{c}\text { Dalka do Brasil LTDA } \\
\text { (Grupo Rotoplas) }\end{array}$ & 2010 & $\begin{array}{l}\text { Produtos de borracha } \\
\text { e de material plástico }\end{array}$ & 180 & Médio & México \\
\hline $\begin{array}{l}\text { Force-line Ind. e Com. de } \\
\text { Componentes Eletrônicos } \\
\text { LTDA }\end{array}$ & 2006 & Produtos eletrônicos & 136 & Médio & São Paulo \\
\hline Ball do Brasil LTDA & 2016 & Produtos de metal & 132 & Médio & EUA \\
\hline $\begin{array}{l}\text { CNS Central de Núcleos } \\
\text { Siliciosos EIRELI }\end{array}$ & 2010 & Metalurgia & 120 & Médio & São Paulo \\
\hline $\begin{array}{c}\text { Excil Comércio e Indústria } \\
\text { LTDA }\end{array}$ & 2008 & Automotivo & 110 & Médio & São Paulo \\
\hline $\begin{array}{c}\text { Barry Callebaut Brasil Ind. e } \\
\text { Com. de Produtos } \\
\text { Alimentícios LTDA }\end{array}$ & 2009 & Produtos alimentícios & 107 & Médio & Bélgica \\
\hline $\begin{array}{c}\text { Barasch Ind. e Comércio de } \\
\text { Produtos Eletroeletrônicos } \\
\text { LTDA }\end{array}$ & 2007 & $\begin{array}{c}\text { Produtos e materiais } \\
\text { elétricos }\end{array}$ & 105 & Médio & São Paulo \\
\hline
\end{tabular}

Fontes: Adaptado do Cadastro das Empresas Ativas (PREFEITURA MUNICIPAL DE EXTREMA, 2017a); do Sinmec (2016); da SEF-MG (2018); das páginas eletrônicas das empresas. Autor: Elias Mendes Oliveira (2018). 
Em sua maioria, as unidades fabris estão relacionadas aos gêneros tradicionais da indústria, normalmente caracterizados pelo uso menos intensivo de tecnologias de ponta e pela produção de produtos com menor valor agregado, como alimentos, componentes para automóveis, artigos em papel e celulose, artigos em borracha e materiais plásticos e metalurgia.

Além disso, os estabelecimentos cujas operações envolvem maior conteúdo tecnológico, como a Multilaser, a Force-line ou a Panasonic, realizam basicamente a montagem industrial de seus produtos em Extrema, enquanto as atividades de pesquisa e desenvolvimento são realizadas nas grandes metrópoles brasileiras ou no exterior. Para essas indústrias, Extrema exerce a função de "plataforma produtiva", onde são executados processos industriais repetitivos, intensivos em trabalho pouco qualificado e que tendem a ser amplamente disseminados entre as indústrias.

No espaço industrial do município, coexistem indústrias bastante segmentadas espacialmente, cuja produção e comercialização de mercadorias ocorrem em escala global, como a Panasonic, a HBA Hutchinson, a Kidde, a Ball, a Fagor Ederlan e a Barry Callebaut; indústrias em fase crescente de internacionalização do capital e da produção, como a Pandurata Alimentos e a Dalka; e empresas que exploram basicamente o mercado interno, como a Delo, a Frum, a Excil, a Multilaser, a Force-line, a CRM Alimentos e a CNS.

A complexidade da organização industrial tende a ser proporcional à capitalização, ao domínio tecnológico, à área de mercado e ao poder de barganha das indústrias. Assim sendo, a fragmentação do processo produtivo e a extensão do mercado consumidor tendem a ser mais expressivas entre as corporações internacionais devido à concentração e centralização do capital, historicamente a seu favor, em relação às indústrias nacionais.

Os grandes estabelecimentos em Extrema são formados por recursos de várias origens, como mostra o Quadro 1. As indústrias estrangeiras são principalmente de países centrais, como a França, a Espanha, a Bélgica, o Japão e os Estados Unidos, evidenciando casos de disjunção espacial da produção.

Entre as empresas de capitais nacionais, há exemplos de desconcentração e de descentralização industrial. Para os casos de desconcentração industrial, as fases mais padronizadas da produção foram localizadas em Extrema, enquanto as atividades mais nobres ou primazes das empresas (gestão, desenvolvimento de pesquisas e de novos produtos, publicidade e propaganda etc.) foram mantidas nas cidades de origem dos investimentos, na Região Metropolitana de São Paulo (RMSP). Esta situação reforça o padrão clássico da desconcentração industrial 
no Brasil, examinado por autores como Mendes (1997) e Selingardi-Sampaio (2009). Entre as indústrias do Quadro 1, a Pandurata Alimentos, a Multilaser, a CRM, a Soft Film, a Barasch, a Force-line e a CNS efetuaram desconcentração industrial para Extrema.

A descentralização industrial, por sua vez, envolve a transferência integral das funções produtivas e administrativas da empresa para outro lugar. A Delo e a Frum constituem as empresas que efetivaram descentralização industrial. A Excil foi fundada em Extrema, porém é mantida por capitais paulistas.

Por último, vale ressaltar que as grandes inversões de origem exógena em Extrema ocorreram a partir de meados dos anos 1990, quando se dispunham das bases técnicas (infraestrutura logística satisfatória, sistemas técnicos que dão suporte à produção, disponibilidade de terrenos etc.) e de conjuntura político-econômica (condições macroeconômicas favoráveis, incentivos fiscais e creditícios etc.) propícias para a reprodução do grande capital da indústria nesta cidade pequena.

Nesse sentido, reafirma-se a tese de que algumas cidades pequenas dispõem de fatores locacionais relevantes para a reprodução do grande capital da indústria atualmente, motivo pelo qual atraem grandes estabelecimentos dedicados, principalmente, às etapas da produção propriamente dita. Cabe, pois, discutir de maneira mais aprofundada tais fatores.

\section{FATORES LOCACIONAIS E AGENTES SOCIAIS LIGADOS À INDUSTRIALIZAC̦Ã̃ RECENTE EM EXTREMA}

A instalação de grandes indústrias em Extrema orientou-se basicamente pela presença de alguns fatores locacionais no território - localização estratégica, mão de obra abundante e barata, ações de instituições públicas e privadas -, que contribuem para a redução dos custos da produção industrial e, por conseguinte, para a reprodução dos capitais investidos.

\section{Localização estratégica}

A localização industrial em Extrema é estratégica porque aspectos ligados à posição geográfica e ao sítio urbano do município contribuem para a redução dos custos operacionais do processo produtivo. De modo geral, a posição geográfica remete à escala interurbana e refere-se aos diferenciais de acessibilidade aos fatores de produção e aos mercados entre as localizações possíveis para as indústrias no território. $\mathrm{O}$ sítio urbano, por sua vez, diz respeito às infraestruturas 
e aos serviços que dão suporte imediato à produção na escala intraurbana, como os sistemas técnicos de energia elétrica, de saneamento básico, de telecomunicações etc. ou à presença de distritos industriais.

No tocante à posição geográfica, Extrema localiza-se no Sul e Sudoeste de Minas Gerais, mais precisamente na microrregião de Pouso Alegre, a $480 \mathrm{~km}$ de Belo Horizonte (MG), 100 km de São Paulo (SP) e 500 km do Rio de Janeiro (RJ), ou seja, na área de maior concentração industrial, econômica, demográfica e urbana do país. A proximidade da metrópole paulistana, em particular, constitui elemento-chave para a industrialização local, haja vista a densidade e a diversidade das infraestruturas econômicas e do mercado consumidor disponíveis na maior metrópole brasileira.

A distância reduzida e as facilidades logísticas, principalmente através da BR 381, em relação à fração mais dinâmica do território nacional, possibilitam às indústrias o acesso mais rápido e econômico aos bens materiais e imateriais e ao mercado consumidor. Nesse sentido, a posição geográfica de Extrema é estratégica porque imprime celeridade ao processo de valorização do capital no território, ou seja, contribui para a reprodução ampliada dos capitais e para a maior competitividade das indústrias no mercado globalizado.

A diversidade, a densidade e a qualidade dos transportes interferem diretamente no tempo e nos custos das transações econômicas pelo território. A infraestrutura logística de Extrema encontra-se representada no Mapa 1.

A integração da BR 381 com a BR 116 e o Rodoanel, na RMSP, e com a BR 101, em território paulista ou capixaba, amplia as condições de acessibilidade de Extrema em relação ao Rio de Janeiro e às regiões Sul, Nordeste e Centro-Oeste. Destarte, as facilidades logísticas representadas pela BR 381 são fundamentais para a localização industrial em Extrema, assegurando a fluidez territorial necessária para a reprodução do capital.

A MG 460, por sua vez, consiste em uma rodovia estadual, com aproximadamente $40 \mathrm{~km}$ e pista simples. Estende-se do entroncamento com a BR 381, em Extrema, até o município de Munhoz (MG), passando por Toledo (MG), duas cidades pequenas da microrregião de Pouso Alegre.

$\mathrm{O}$ acesso aos principais aeroportos do país é essencial para viagens a longa distância, sendo correntemente utilizado por técnicos e executivos das indústrias ou para o transporte de cargas com maior valor agregado. Nas proximidades de Extrema, existem terminais de carga em Viracopos, Guarulhos e São José dos Campos, facilmente acessíveis a partir da BR 381(Mapa 1). 
Mapa 1 - Infraestrutura logística de Extrema no território nacional - 2018.

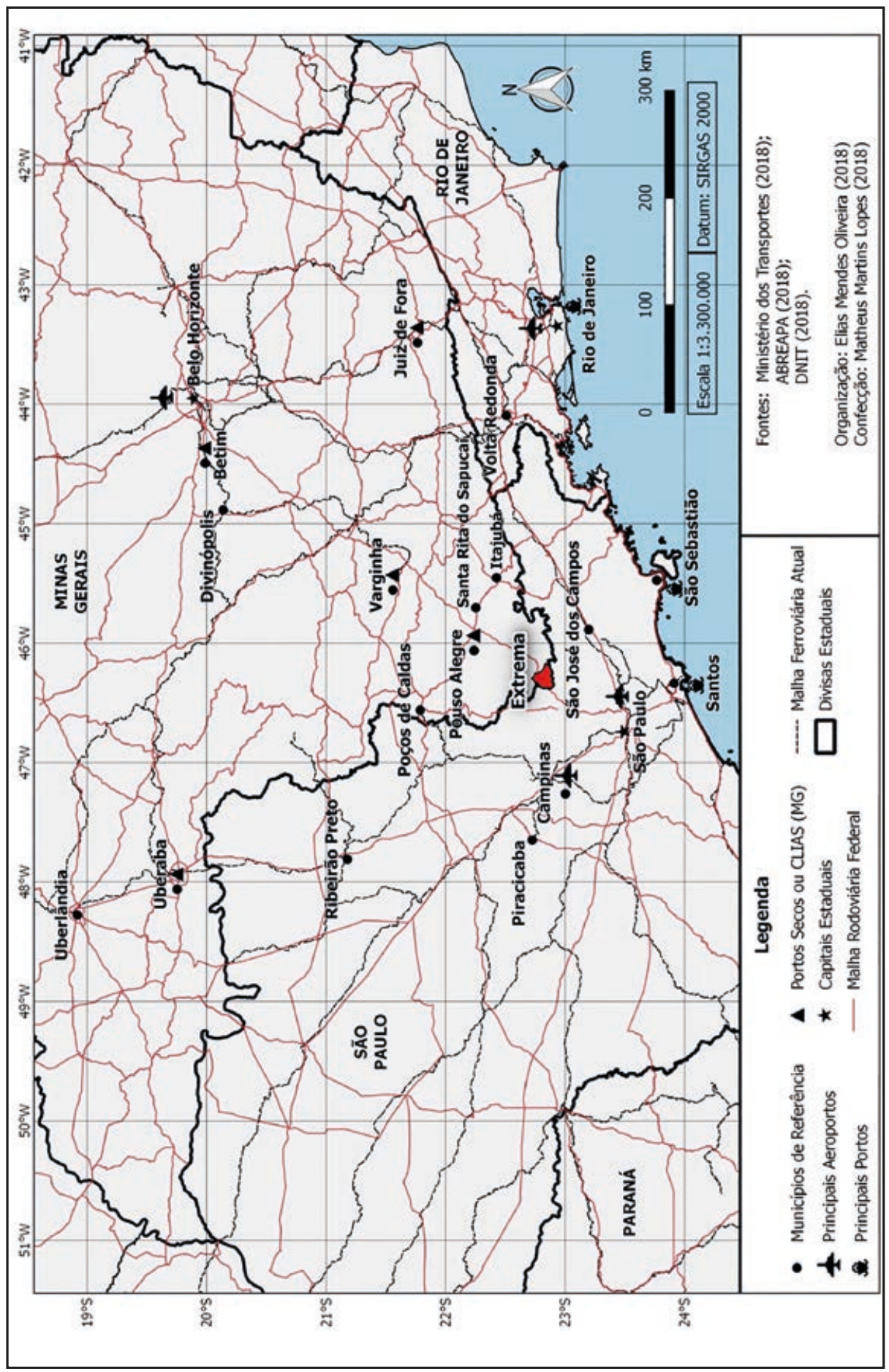

Autor: Elias Mendes Oliveira (2018). 
A posição geográfica do município também privilegia o comércio exterior por meio dos portos de Santos, de São Sebastião e do Rio de Janeiro (Mapa 1). Muitos insumos utilizados na produção em Extrema são importados e algumas indústrias exportam suas mercadorias, reforçando a importância do acesso facilitado às instalações portuárias.

A proximidade aos portos secos e aos Centros Logísticos Industriais e Aduaneiros (Clias), em Minas Gerais, constitui outra vantagem locacional para as indústrias que praticam o comércio internacional. Nesses entrepostos ocorre o controle aduaneiro sobre a movimentação, a armazenagem e o despacho de mercadorias advindas ou destinadas ao exterior. No Sul e Sudoeste de Minas Gerais estão localizados o Porto Seco Sul de Minas, em Varginha (MG), e o Clia Sul de Minas, em Pouso Alegre (Mapa 1).

Além dos transportes, a localização industrial em Extrema favorece especificamente alguns gêneros industriais, como aqueles que fabricam bens intermediários para a indústria automobilística. O Mapa 2 mostra a posição geográfica de Extrema em relação às principais montadoras de automóveis na Região Sudeste do Brasil.

À exceção das unidades fabris situadas na porção central de Minas Gerais (Betim, Contagem e Sete Lagoas), as principais montadoras de automóveis estão dispostas em uma espécie de "arco industrial" - interligando Juiz de Fora (MG) a Ribeirão Preto (SP) - em relação ao território de Extrema. Por conseguinte, a posição geográfica facilita os intercâmbios entre as unidades fabris na cidade, como a HBA Hutchinson, a Fagor Ederlan, a Frum, a Kidde e a Excil, e as indústrias automobilísticas nas adjacências, reduzindo os custos das transações econômicas na produção veicular.

Assim sendo, a posição geográfica de Extrema assegura a fluidez territorial necessária para a reprodução dos capitais da indústria, ao mesmo tempo em que intensifica os vínculos e as trocas espaciais entre o município e outras localidades no Brasil e no mundo.

No que concerne às vantagens locacionais ligadas ao sítio urbano, o território de Extrema está equipado com as infraestruturas e os serviços urbanos que dão suporte imediato à produção industrial, como os sistemas de distribuição de energia elétrica, de abastecimento de água tratada, de esgotamento sanitário e de telecomunicações, além de serviços bancários, do corpo de bombeiros etc. $\mathrm{Na}$ medida em que as infraestruturas e os serviços urbanos encontram-se cada vez mais difundidos pelo país, principalmente no Centro-Sul, a sua disponibilidade no território local não constitui, a priori, o elemento central para a localização industrial em Extrema, atualmente. 
Mapa 2 - Posição geográfica de Extrema (MG) em relação às principais montadoras de automóveis da Região Sudeste - 2017.

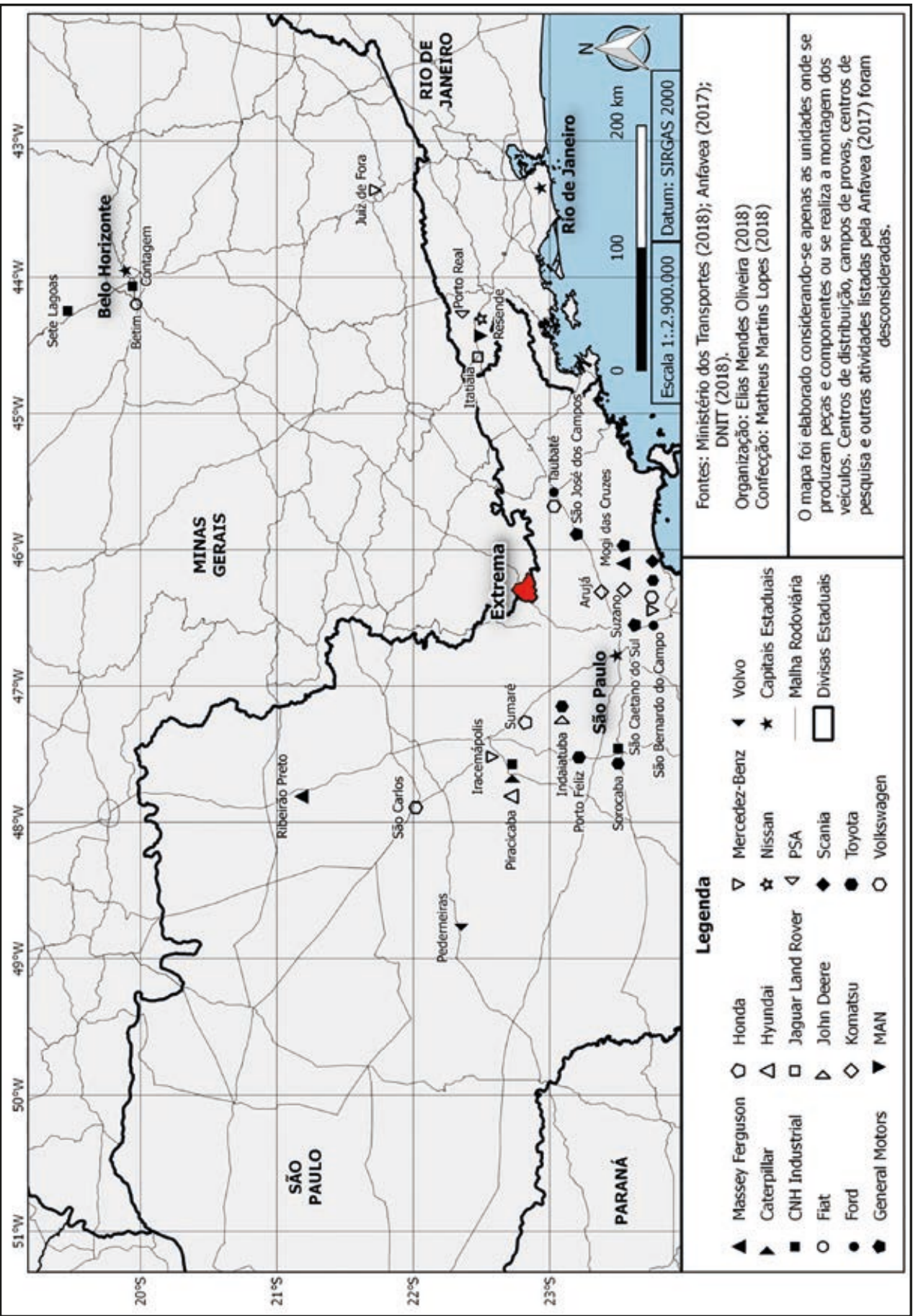

Autor: Elias Mendes Oliveira (2018). 
O principal aspecto para a instalação de grandes fábricas em Extrema em relação ao sítio urbano diz respeito à presença de distritos industriais bem posicionados em relação à $\mathrm{BR} 381$, acarretando facilidades logísticas na circulação de insumos, mercadorias e trabalhadores das indústrias.

Oliveira (1976) define os distritos industriais como espaços planejados especialmente para abrigar a atividade industrial e que são utilizados, simultaneamente, como instrumentos de indução e de ordenamento do uso industrial do território. Em geral, as vantagens da localização nos distritos industriais remontam à disponibilidade de terrenos mais amplos e baratos do que em outras partes da cidade; à adequação das infraestruturas às operações industriais; às facilidades logísticas para a obtenção de matérias-primas, para o escoamento de produção e para a circulação dos trabalhadores; à possibilidade de integração com outras indústrias; à menor incidência de conflitos com a vizinhança, decorrentes da produção industrial (ruídos, mau cheiro, congestionamentos, poluição etc.), entre outros.

Atualmente, Extrema conta com três distritos industriais. Segundo Carvalho (2018), todos são pavimentados e dispõem de água encanada, esgotamento sanitário, iluminação pública e limpeza periódica. O Distrito Industrial dos Pires está localizado junto ao acesso sul da cidade, pela BR 381, próximo à divisa com São Paulo. Abriga grandes indústrias, como a Multilaser, a Force-line, a Dalka, a Pandurata Alimentos, e os centros de distribuição da Centauro, da Netshoes e da Nakata Automotiva. O Distrito Industrial dos Pessegueiros I situa-se às margens da BR 381, no extremo nordeste do município, onde estão localizadas a Ball e os centros de distribuição da Johnson \& Johnson e da Biolab Farmacêutica. O Distrito Industrial dos Pessegueiros II é circundado pela Rodovia Fernão Dias, onde estão localizadas a CNS, a Mlaser, a Nasha e a Festcolor.

Até meados dos anos 2000, Carvalho (2018) esclarece que a ocupação dos distritos industriais era incentivada pela doação de terrenos, muitos dos quais de grandes dimensões. Todavia, o esgotamento das reservas de imóveis da Prefeitura Municipal de Extrema inviabilizou as doações para grandes empreendimentos, contemplando apenas algumas indústrias de micro e pequeno porte. Desde então, as grandes indústrias que se instalaram no município negociaram lotes diretamente com os proprietários fundiários.

A periferização das indústrias constitui a principal tendência da localização intraurbana das unidades fabris em Extrema, sendo influenciada tanto pelas políticas de ordenamento do território quanto pela necessidade de grandes superfícies dotadas de infraestruturas e facilidades logísticas (como o acesso fácil à BR 381) por parte das indústrias. 
A maioria das indústrias em Extrema, principalmente as de médio e grande porte, distribuem-se ao longo da BR 381 e da Avenida Nicolau Cesarino, conformando um "eixo industrial" no sentido sudoeste-nordeste, que integra os distritos industriais da cidade. As unidades fabris estão concentradas principalmente nos Bairros dos Pires, da Ponte Alta, do Barreiro, dos Tenentes, do Rodeio, da Roseira e dos Pessegueiros.

De modo geral, a implantação periférica das indústrias minimiza as deseconomias de aglomeração comumente associadas à localização central ou pericentral em Extrema, embora se observem a incidência gradual de congestionamentos na Avenida Nicolau Cesarino e o aumento do número de acidentes envolvendo caminhões na BR 381.

\section{Mão de obra abundante e barata}

A relevância da mão de obra como fator locacional para as indústrias varia de acordo com o perfil (diferenciação por sexos, escolaridade média, qualificação, conhecimentos tácitos etc.), os salários, a organização (sindicatos, associações, cooperativas etc.) e o contingente de trabalhadores existente nos lugares, respeitadas as diferenciações de tamanho, gênero industrial, domínio tecnológico, formas de organização industrial e capitalização entre as unidades produtivas.

Com a fragmentação espacial da produção, o peso da mão de obra nas escolhas locacionais depende cada vez mais da natureza dos processos produtivos desenvolvidos em cada lugar. Em Extrema, as grandes indústrias desenvolvem principalmente as fases da produção propriamente dita, intensivas em trabalho para a execução de processos repetitivos e com menor grau de complexidade tecnológica.

Destarte, a produção industrial em Extrema envolve grande quantidade de postos de trabalho, preenchidos predominantemente por operários com menor grau de escolaridade média. A disponibilidade e os baixos salários qualificam a mão de obra como fator locacional para as grandes indústrias nas três últimas décadas no município.

As ações das grandes indústrias influenciam diretamente o mercado laboral, tanto na quantidade quanto na categoria dos postos de trabalho ofertados. De acordo com o Ministério do Trabalho e do Emprego (MTE, 2016) ${ }^{3}$, as indústrias

3 Em números absolutos, no último dia de 2016, o número de empregos formais contabilizados pelo MTE (2016), em Extrema, foram: a) 7, na extração mineral; b) 8.787, na indústria de transformação; c) 24, nos serviços industriais de utilidade pública; d) 124, na construção civil; e) 3.205, no comércio; f) 3.926, nos serviços; g) 620, na administração pública; h) 196, 
de transformação foram responsáveis por 52,03\% dos empregos em Extrema, no final de 2016, enquanto os serviços, o comércio, a administração pública, a agropecuária, a construção civil, os serviços industriais de utilidade pública e a extração mineral criaram, respectivamente, 23,24\%, 18,98\%, 3,67\%, 1,16\%, $0,74 \%, 0,14 \%$ e $0,04 \%$ do total de ocupações. A especialização do mercado de trabalho na transformação industrial constitui um indício de que Extrema foi convertida recentemente em uma "cidade pequena industrial".

Segundo informações extraídas MTE (2016) ${ }^{4}$, as funções que mais admitiram funcionários em Extrema, no final de 2016, em ordem decrescente, foram: alimentador de linha de produção (16,4\%), faxineiro (4,79\%), almoxarife $(4,14 \%)$, operador de forno para fabricação de pães, biscoitos e similares (3,59\%) e montador de equipamentos eletrônicos, como computadores e equipamentos auxiliares (3,53\%). Em conjunto, estas cinco profissões conceberam 32,45\% das oportunidades de trabalho no município e caracterizam-se pelo caráter repetitivo das atividades, pela baixa escolaridade média e, consequentemente, pelos salários reduzidos.

Os cargos diretamente relacionados à produção industrial - alimentador de linha de produção, operador de forno e montador de equipamentos eletrônicos contabilizaram 23,52\% do total de empregos em Extrema, quantidade superior à contribuição de quaisquer setores de atividade econômica no município (MTE, 2016). Entre as indústrias de transformação, a representatividade dos referidos cargos alcançou 45,21\% do total de ocupações, no término de 2016 (MTE, 2016).

Na medida em que os alimentadores de linhas de produção, os operadores de forno e os montadores de equipamentos eletrônicos realizam funções próprias ao "chão de fábrica" e considerando o peso dos referidos cargos no mercado de trabalho local, é possível qualificar Extrema como "lócus da produção propriamente dita" na divisão territorial do trabalho da indústria vigente.

A influência das maiores indústrias na geração de empregos e o preenchimento diferenciado das vagas por sexo são perceptíveis em Extrema. Conforme indicadores do MTE $(2016)^{5}$, o cargo de operador de fornos para a fabricação de

na agropecuária. Naquele momento, o número de empregos formais em Extrema totalizou 16.889 postos de trabalho (MTE, 2016).

4 Em números absolutos, as profissões com maior oferta de empregos formais em Extrema, em 31/12/2016, foram: alimentador de linhas de produção (2.771 vagas), faxineiro (809 vagas), almoxarife (699 vagas), operador de forno (606 vagas) e montador de equipamentos eletrônicos (596 vagas) (MTE, 2016).

5 Em 31/12/2016, as 606 vagas para operador de forno foram preenchidas por 314 homens e 292 mulheres; enquanto as 596 vagas para montador de equipamentos eletrônicos foram ocupadas por 67 homens e 529 mulheres (MTE, 2016). 
pães, biscoitos e similares está diretamente vinculado à Pandurata Alimentos e caracterizou-se por certo equilíbrio na ocupação das vagas: $51,81 \%$ de homens e 48,19\% de mulheres. Por outro lado, a função de montador de equipamentos eletrônicos, amplamente executada por mulheres - 88,75\% contra $11,25 \%$-, está associada a indústrias como a Multilaser e a Force-line.

A baixa escolaridade média dos funcionários consiste em outra característica dos cargos que disponibilizaram a maior quantidade de empregos formais em Extrema. Marques et al. (2018) apontam que "a maioria das empresas só contrata com segundo grau completo. Tem muita gente que tem menos estudo e faz os trabalhos com remuneração menor ainda, braçal mesmo...".

O vencimento médio entre as indústrias de transformação foi de $2.493,48$, no encerramento de 2016. Naquele período, a indústria de transformação pagou, em média, o quarto maior vencimento em Extrema, atrás da administração pública $(-29,6 \%)$, dos serviços industriais de utilidade pública (-10,74\%) e da agropecuária $(-9,29 \%)$, mas à frente do comércio $(29,85 \%)$, da construção civil $(44,59 \%)$, dos serviços $(51,34 \%)$ e da extração mineral $(116,47 \%)$, como indicam os dados do MTE (2016) ${ }^{6}$.

No entanto, as indústrias de transformação contribuíram com a maior parcela da massa salarial em Extrema, devido ao grande número de postos de trabalhos gerados nas unidades fabris. Assim sendo, além da primazia na geração de empregos, a transformação industrial constitui a principal atividade econômica responsável pela geração de renda no município, haja vista o volume de capitais injetados na economia e suas implicações sobre a expansão e a diversificação da base produtiva local.

Entre os cinco principais cargos demandados pelas indústrias de transformação, receberam os maiores salários, em média e em ordem decrescente, os operadores de forno ( $\mathrm{R} \$ 2.397,74)$, os almoxarifes ( $\mathrm{R}$ \$ 2.029,22), os montadores de equipamentos eletrônicos ( $\mathrm{R}$ 1.534,26), os alimentadores de linha de produção ( $\mathrm{R} \$ 1.472,38)$ e os faxineiros ( $\$$ \$ 952,47) (MTE, 2016).

Em média, estas cinco profissões tiveram remunerações inferiores à média das indústrias de transformação $(\mathrm{R} \$ 2.493,48)$, em 2016. Em relação à média

6 Os valores médios das remunerações em Extrema, no final de 2016, foram: a) R\$ 1.151,86, na extração mineral; b) R \$ 2.493,48, na indústria de transformação; c) R \$ 2.793,47, nos serviços industriais de utilidade pública; d) R\$ 1.724,46, na construção civil; e) R\$1.920,22, no comércio; f) R \$ 1.647,60, nos serviços; f) R \$ 3.541,71, na administração pública; e g) R\$ 2.748,78, na agropecuária (MTE, 2016). 
salarial do município ( $\mathrm{R} \$ 2.227,33)$, apenas os operadores de forno embolsaram quantias ligeiramente superiores, no valor de R\$170,41 reais (MTE, 2016).

Entre homens e mulheres, a discrepância nas remunerações médias é ainda mais nítida, porque os salários médios para pessoas do sexo feminino foram inferiores aos indivíduos do sexo masculino. Por ocupação, o vencimento das mulheres foi $20,72 \%, 19,62 \%, 16,42 \%, 9,1 \%$ e $1,63 \%$ menor do que para os homens nos cargos de faxineiro, alimentador de linhas de produção, almoxarife, operador de forno e montador de equipamentos eletrônicos, respectivamente (MTE, 2016) ${ }^{7}$. Nesse sentido, as diferenças nas contratações e no valor dos salários entre homens e mulheres constituem vantagens comparativas para as indústrias de transformação em Extrema.

De modo geral, os números do MTE (2016) comprovam os baixos custos da mão de obra em Extrema, principalmente entre os cargos mais demandados pelas indústrias. O emprego de mão de obra barata, com menor grau de escolaridade média, reproduzindo as desigualdades salariais históricas entre homens e mulheres, condiz com o papel desempenhado por Extrema na divisão territorial do trabalho da indústria como "lócus da produção propriamente dita".

Vale lembrar que os menores custos da mão de obra estimulam a transferência das fases mais padronizadas da produção dos grandes centros urbano-industriais, como algumas cidades paulistas (São Paulo, Campinas, São Bernardo do Campo, São José dos Campos etc.) para cidades do Sul e Sudoeste de Minas, como Extrema, Pouso Alegre, Varginha ou Três Corações.

Além disso, Extrema possui menor organização sindical se comparada às cidades com maior tradição industrial. De modo geral, a sindicalização dos trabalhadores representa deseconomia de aglomeração para as indústrias, porque intensifica as pressões pela valorização do trabalho perante o capital.

Obviamente, existem instituições representativas ${ }^{8}$ dos trabalhadores em Extrema, porém com menor tradição e poder de barganha do que os sindica-

7 No encerramento de 2016, a média salarial das profissões com maior oferta de empregos formais em Extrema, entre os homens, foi de: a) R \$ 1.623,05, para alimentadores de linhas de produção; b) $R$ \$ 1.167,37, para faxineiros; c) $\mathrm{R} \$ 2.122,26$, para almoxarifes; d) $\mathrm{R} \$ 2.507,65$, para os operadores de forno; e e) $\mathrm{R} \$ 1.556,77$, para os montadores de equipamentos eletrônicos. Entre as mulheres, as remunerações médias, para os mesmos cargos, foram de: R\$ 1.304,59; R \$ 925,53; R \$ 1.773,72; R \$ 2.279,44 e R \$ 1.531,77, respectivamente (MTE, 2016).

8 Os sindicatos dos trabalhadores das indústrias localizados em Extrema são: o Sindicato das Indústrias de Alimentação e Panificação de Extrema e Região (Sindalex), o Sindicato dos Trabalhadores nas Indústrias Metalúrgicas, Mecânicas e de Material Elétrico de Extrema, Itapeva e Camanducaia (Stimeic) e o Sindicato dos Trabalhadores nas Indústrias do Ramo 
tos que atuam nos grandes centros urbano-industriais. Ao que tudo indica, a celeridade da industrialização local, somada ao atual cenário do sindicalismo brasileiro, explica essa menor adesão e expressividade do movimento sindical em Extrema.

Os efeitos da concentração de estabelecimentos e de empregos industriais não ficam circunscritos a Extrema, porque o contingente de operários no município é insuficiente para suprir a demanda das indústrias (CARVALHO, 2018). A disponibilidade de postos de trabalho nas indústrias estimulou uma série de movimentos migratórios - êxodo rural, migrações pendulares e inter-regionais - que têm a cidade de Extrema como destino. Os principais impactos dos deslocamentos populacionais sobre a dinâmica socioespacial do município são a urbanização acelerada, a demanda crescente por habitação, infraestrutura urbana e serviços públicos, a especulação imobiliária, o aumento dos fluxos materiais e imateriais pelo território e o maior alcance das interações espaciais.

Apesar de recrutar indivíduos com baixo grau de escolaridade média, muitos processos industriais exigem o domínio de técnicas específicas capazes de otimizar a produção. O conhecimento dessas técnicas, usualmente, não está disseminado entre os munícipes e os imigrantes que executam as tarefas do "chão de fábrica". Em geral, as pessoas contratadas pelas indústrias ocupavam-se de atividades agrícolas, portanto, não estão habituadas aos processos rotinizados que caracterizam a atividade industrial.

Nesse sentido, a velocidade das transformações socioespaciais em Extrema, a partir da industrialização, contrapõe duas lógicas aparentemente conflitantes. De um lado, as indústrias requerem a valorização rápida do capital, exigindo, para tanto, o ajustamento do território as suas necessidades quanto às infraestruturas econômicas e sociais que dão suporte à produção. Por outro lado, o lugar dispõe de uma dinâmica socioespacial previamente estabelecida, fruto da evolução histórica dos diferentes usos do território (agropecuária, turismo, chacreamento etc.), condicionando as relações sociais, o cotidiano e as interações espaciais do município.

Assim sendo, as contradições entre o antigo e o novo, entre o capital e o trabalho e entre o mercado e o Estado se apresentam como desafios para a sociedade e o poder local. Ao mesmo tempo em que as indústrias geram emprego e renda ou elevam a arrecadação de impostos no município, suas operações resultam, entre outros fatores, em maior demanda por habitação e pelos serviços

Químico, Petroquímico, Farmacêutico, Plásticos, Tintas, Vernizes, Resinas, Sintéticas e Produtos do Toucador de Extrema, Itapeva, Munhoz e Toledo (Stiquimi). 
de utilidade pública, problemas de saúde, especulação imobiliária e aumento das pressões antrópicas sobre o meio ambiente.

Com o objetivo de minimizar a falta de preparo dos indivíduos para o trabalho industrial, os agentes sociais diretamente envolvidos na industrialização local organizaram-se no sentido de implantar em Extrema uma unidade do Serviço Nacional de Aprendizagem Industrial (Senai), instituição amplamente reconhecida na formação de quadros técnicos especializados para a indústrias.

A unidade Janez Hlebanja do Senai foi inaugurada na cidade em 1997 e atualmente oferece cursos nas áreas de eletroeletrônica, gestão, metalmecânica, normas regulamentadoras e tecnologia da informação, qualificando os operários basicamente para as funções do "chão de fábrica" e de apoio administrativo.

O provimento dos cargos para as funções que exijam formação de nível superior (graduação e/ou pós-graduação), como engenharias, contabilidade, administração, direito etc., representa um entrave para a produção industrial em Extrema. Esses profissionais normalmente são recrutados em cidades médias ou grandes do entorno, como Bragança Paulista (SP), Atibaia (SP), São José dos Campos (SP), Pouso Alegre (MG), Campinas (SP) ou São Paulo (SP).

A fundação da Faculdade de Ciências Sociais Aplicadas de Extrema (Faex), em 2002, objetivou justamente minimizar a falta de profissionais de nível superior em Extrema, explorando um nicho de mercado derivado da expansão industrial no município. Os cursos oferecidos pela Faex, principalmente nas áreas de engenharias e ciências sociais aplicadas, possuem relação direta com os perfis profissionais requisitados pelas indústrias.

Na medida em que a criação da Faex foi amplamente assistida pela Prefeitura Municipal de Extrema, pode-se afirmar que as políticas locais de fomento às indústrias não se restringem à isenção dos impostos municipais ou à implementação de infraestruturas, estendendo-se às medidas que objetivam aprimorar o mercado de trabalho. Em última instância, tais ações procuram elevar o nível salarial médio no município, potencializando a oferta de bens e de serviços mais qualificados, bem como a circulação de capitais na economia.

Em síntese, o significado da mão de obra como fator locacional para as indústrias depende da natureza dos processos industriais por elas introduzidos em Extrema, ou seja, as etapas da produção propriamente dita, intensivas em mão de obra barata. Todavia, o crescimento industrial no município não se limita a fatores locacionais de expressão regional (localização estratégica, mão de obra abundante e barata), compartilhados com outras cidades pequenas da microrregião, como Itapeva ou Camanducaia. Na realidade, o entendimento da 
expansão industrial em Extrema suscita o exame das ações empreendidas pelos agentes sociais diretamente envolvidos no processo de industrialização local, quais sejam: o Governo de Minas Gerais, a Prefeitura Municipal de Extrema e as instituições privadas ligadas à indústria, como a Federação das Indústrias do Estado de Minas Gerais (Fiemg), o Senai e o Sindicato das Indústrias Metalúrgicas e Mecânicas e de Materiais Elétricos de Cambuí, Camanducaia, Extrema e Itapeva (Sinmec).

\section{Ações do governo estadual}

A administração estadual é a grande parceira da Prefeitura Municipal de Extrema no fomento à industrialização no território, participando ativamente da atração de grandes investimentos de origem exógena ao município.

De acordo com Dulci (2000), Minas Gerais detém longa tradição na implementação de políticas públicas destinadas ao desenvolvimento industrial, cujos objetivos são: a) ampliar e diversificar a estrutura produtiva do estado; b) promover o desenvolvimento socioeconômico mais equilibrado entre suas regiões; c) elevar a representatividade política e econômica de Minas Gerais no Brasil.

No contexto da guerra fiscal dos lugares, as principais estratégias utilizadas pela administração estadual para atrair novos investimentos são: a) a divulgação das vantagens da localização industrial em Minas Gerais junto às empresas nacionais e estrangeiras; b) a articulação com agentes públicos e privados para a viabilização dos empreendimentos industriais; c) a concessão de incentivos fiscais e creditícios às indústrias.

Atualmente, a Secretaria de Desenvolvimento Econômico, Ciência, Tecnologia e Ensino Superior de Minas Gerais (Sedectes) concentra as ações do governo mineiro que visam modernizar as atividades econômicas, atrair novos investimentos e tornar o estado mais competitivo nos cenários nacional e internacional. Para alcançar seus objetivos, a Sedectes apoia-se na atuação das agências estatais elencadas no Quadro 2.

A Agência de Promoção de Investimento e Comércio Exterior de Minas Gerais (Indi) constitui a principal instituição do governo estadual associada ao crescimento industrial e econômico em Extrema (CARVALHO, 2018). De modo geral, o Indi divulga as potencialidades econômicas, define as prioridades e o direcionamento dos investimentos, além de contribuir com o planejamento econômico e territorial em Minas Gerais (INDI, 2018).

As ações do Indi no Sul e Sudoeste de Minas e em Extrema não são recentes. Durante a década de 1970, poucos anos após a criação do órgão, estudos 
técnicos elaborados pela agência estatal já apontavam a mesorregião e o município como destinos prioritários para grandes investimentos da indústria, por força da posição geográfica estratégica no território nacional. A partir da década de 1990, as ações do Indi intensificaram-se em Extrema devido à potencialidade do município para atrair o grande capital da indústria no contexto da globalização neoliberal, da desconcentração industrial e da guerra fiscal dos lugares.

Quadro 2 - Agências estatais de fomento à atividade econômica em Minas Gerais - 2018.

\begin{tabular}{|c|c|c|c|}
\hline \multicolumn{2}{|c|}{ Agência estatal } & Fundação & Competências principais \\
\hline BDP & $\begin{array}{l}\text { Banco de } \\
\text { Desenvolvimento de } \\
\text { Minas Gerais }\end{array}$ & 1962 & $\begin{array}{l}\text { Financiamento de projetos do setor pú- } \\
\text { blico e privado, disponibilizando linhas } \\
\text { de crédito para empresas de todos os } \\
\text { portes e setores; participação em fun- } \\
\text { dos de investimento ligados à inovação } \\
\text { e sustentabilidade. }\end{array}$ \\
\hline & $\begin{array}{c}\text { Companhia Energética de } \\
\text { Minas Gerais }\end{array}$ & 1952 & $\begin{array}{l}\text { Fornecimento de eletricidade e desen- } \\
\text { volvimento de fontes alternativas de } \\
\text { energia (solar e eólica). }\end{array}$ \\
\hline AIG & $\begin{array}{l}\text { Companhia de } \\
\text { Desenvolvimento } \\
\text { Econômico } \\
\text { de Minas Gerais }\end{array}$ & 2003 & $\begin{array}{l}\text { Investimentos em três grandes eixos es- } \\
\text { tratégicos: indústria de mineração, } \\
\text { energia e infraestrutura; indústria de } \\
\text { alta tecnologia; e indústria criativa; ad- } \\
\text { ministração de distritos industriais } \\
\text { criados pelo estado. }\end{array}$ \\
\hline GA $\int N$ & $\begin{array}{l}\text { Companhia de Gás de } \\
\text { Minas Gerais }\end{array}$ & 1986 & $\begin{array}{l}\text { Distribuição de gás natural canaliza- } \\
\text { do no estado para indústrias (gás na- } \\
\text { tural comprimido e liquefeito), condo- } \\
\text { mínios (residencial) e pessoas físicas } \\
\text { (automotivo). }\end{array}$ \\
\hline FAPEMIG & $\begin{array}{l}\text { Fundação de Amparo } \\
\text { à Pesquisa do Estado de } \\
\text { Minas Gerais }\end{array}$ & 1985 & $\begin{array}{l}\text { Indução e fomento à pesquisa e à ino- } \\
\text { vação científica e tecnológica no esta- } \\
\text { do; apoio a projetos diversos por meio } \\
\text { de linhas de crédito, consultoria e ca- } \\
\text { pacitação. }\end{array}$ \\
\hline INDI & $\begin{array}{l}\text { Agência de Promoção de } \\
\text { Investimento e Comércio } \\
\text { Exterior de Minas Gerais }\end{array}$ & 1968 & $\begin{array}{l}\text { Prospecção, indução e atração de inves- } \\
\text { timentos e assistência aos empreendi- } \\
\text { mentos no estado. }\end{array}$ \\
\hline $\mathbf{J U}$ & $\begin{array}{c}\text { Junta Comercial do Estado } \\
\text { de Minas Gerais }\end{array}$ & 1893 & $\begin{array}{l}\text { Registro público de empresas mais rápi- } \\
\text { do do Brasil, com o prazo médio de } \\
\text { nove dias para formalização dos reque- } \\
\text { rimentos. }\end{array}$ \\
\hline
\end{tabular}

Fonte: Adaptado do Indi (2018). 
A associação entre o Governo de Minas Gerais (e do Indi, em particular) e a Prefeitura Municipal de Extrema tornou-se mais profícua entre 2003 e 2014, quando o mesmo partido político comandava, simultaneamente, a administração estadual e local. Naquele período, ocorreram os maiores volumes de investimentos da indústria no município, como evidencia o Quadro 1.

Não há dúvidas de que a colaboração entre os governos estadual e municipal, nos anos 2000, foi fundamental para a emergência de Extrema como destino preferencial para grandes indústrias em Minas Gerais (e mesmo no Brasil). A criação de um ambiente institucional e normativo propício à reprodução dos capitais da indústria, alinhando as iniciativas do governo estadual (subvenções fiscais, linhas especiais de crédito) e municipal (isenções fiscais, provisão de infraestruturas, doação de terrenos), explica o crescimento industrial mais intenso em Extrema do que em outras cidades pequenas da microrregião de Pouso Alegre.

A alternância de poder em Minas Gerais modificou, em partes, a capacidade de Extrema de atrair investimentos industriais de maior monta. Ainda que o parque industrial do município permaneça dinâmico, com a introdução de novos recursos de procedência exógena, desde a mudança de partido no governo estadual, em 2015, localizaram-se na cidade principalmente estabelecimentos de pequeno ou médio porte, além dos centros de distribuição, ampliando o papel de Extrema como entreposto comercial e logístico.

Mesmo que a qualidade das relações entre a administração estadual e local tenha se modificado em relação aos anos 2000, permanece o objetivo de ambas as esferas de governo de atrair novos investimentos para o estado e o município, principalmente com a crise político-econômica no país, a partir de 2014. Nesse sentido, conforme Carvalho (2018), persiste a parceria entre a Prefeitura Municipal de Extrema e o Indi, no sentido de manter o município competitivo na guerra fiscal dos lugares.

À semelhança das outras unidades federativas do Brasil, Minas Gerais também concede incentivos fiscais e creditícios às empresas como estratégia para angariar novos investimentos na guerra fiscal dos lugares. Os benefícios estaduais são negociados inicialmente pelo Indi; em seguida, os acordos pactuados com as empresas são remetidos ao Banco de Desenvolvimento de Minas Gerais (BDMG), no caso da oferta de linhas especiais de crédito, ou à Assembleia Legislativa de Minas Gerais (ALMG) e à Secretaria de Estado de Fazenda de Minas Gerais (SEF-MG) para apreciação e formalização, respectivamente, dos incentivos fiscais (ALMG, 2018). 
O acesso facilitado ao crédito é empregado com o objetivo de estimular a atividade econômica e atrair novos empreendimentos para o estado, elevando a geração de emprego e renda. Por meio do BDMG, o governo mineiro disponibiliza linhas de crédito específicas às empresas de micro, pequeno, médio ou grande porte (ALMG, 2018).

Os incentivos fiscais, por sua vez, visam "[...] promover o desenvolvimento de atividades, segmentos e setores da economia ou regiões, condicionar comportamentos, bem como favorecer grupos ou parcelas da população" (ALMG, 2018). Em âmbito estadual, os incentivos fiscais incidem principalmente sobre o ICMS $^{9}$.

A isenção fiscal constitui o instrumento mais efetivo do governo estadual para captar investimentos externos, uma vez que, ao desonerar a produção, tais benefícios exercem influência sobre os empresários em suas escolhas locacionais. Em outras palavras, por meio das subvenções fiscais são criadas "condições artificiais" de atração das indústrias, mudando a qualidade dos lugares enquanto destinos "espontâneos" para a localização industrial.

A competição entre estados e municípios pelo grande capital, utilizando-se da isenção total ou parcial do ICMS, está, inclusive, no centro dos debates sobre a guerra fiscal dos lugares no Brasil, processo que contribuiu decisivamente para o crescimento industrial em Extrema, desde meados dos anos 1990.

Em resumo, a administração estadual constitui um dos agentes centrais no modelo de industrialização implementado em Extrema nas últimas décadas, negociando com as empresas os incentivos fiscais e creditícios com maior impacto na desoneração da produção. Encabeçadas pelo Indi, as ações do governo estadual, em interlocução com o poder local, visam à criação de um ambiente propício ao desenvolvimento das indústrias no município em um contexto de disputa entre os entes subnacionais pelo grande capital, em circulação nas escalas nacional ou global.

\section{Ações do governo municipal}

A administração local consiste na grande protagonista da industrialização recente em Extrema, afinal, desde que assumiu a Prefeitura Municipal, em 1989, o grupo político que se mantém no poder participa ativamente da promoção e da organização do espaço industrial.

9 De acordo com a ALMG (2018), o Decreto no 43.080/2002 (MINAS GERAIS, 2002) constitui o documento-base que regulamenta a incidência, a cobrança e a isenção do ICMS em Minas Gerais. 
A passagem da década de 1980 para 1990 caracterizou-se pela redefinição dos papéis exercidos pelo Estado Nacional em uma conjuntura marcada pela redemocratização do país, pela disseminação do neoliberalismo, pela abertura e desregulamentação do mercado nacional, pela globalização e pela guerra fiscal dos lugares.

Naquele contexto, o autofinanciamento das políticas públicas atribuídas aos municípios pela Constituição Federal de 1988 tornou-se questão prioritária para o grupo político que ascendia ao poder local. A industrialização baseada em grandes investimentos de origem exógena foi a alternativa encontrada para gerar emprego e renda, dinamizar a economia e elevar a arrecadação tributária, no curto e médio prazo, em Extrema.

Obviamente, muitas cidades pequenas procuram estimular a industrialização local recorrendo à isenção de impostos municipais, à provisão de infraestruturas ou à criação de distritos industriais, tendo em vista os efeitos de motricidade sobre a economia e o território, historicamente associados ao setor secundário.

No entanto, são poucas as cidades pequenas que atraíram grandes capitais da indústria no Brasil, até o momento. A industrialização é um processo complexo, em que interagem múltiplos fatores - posição geográfica, perfil e custos da mão de obra, desenvolvimento de tecnologia, linhas de financiamento, presença de insumos e densidade do mercado consumidor etc., além da vontade política no sentido de promovê-la.

Ao que tudo indica, no caso de Extrema, os administradores públicos souberam interpretar as principais tendências da dinâmica locacional das indústrias no Brasil sob a influência de processos como a globalização, a desconcentração industrial e a guerra fiscal dos lugares, utilizando-as ao seu propósito. Para tanto, aproveitaram-se de fatores locacionais explorados no território municipal desde a década de 1970, por médias indústrias nacionais - posição geográfica estratégica (principalmente em relação à RMSP), infraestrutura logística favorável (sobretudo após a duplicação da BR 381), baixos salários, abundância de água etc. -, e intensificaram as ações institucionais para atrair e diversificar os investimentos da indústria no município.

As principais medidas empregadas pela administração local para fomentar o desenvolvimento industrial em Extrema foram:

a) a provisão das infraestruturas que dão suporte à produção industrial com recursos próprios (criação de distritos industriais, obras de pavimentação, aterro sanitário etc.) ou em interlocução com as concessionárias de serviços urbanos; 
b) a articulação com outros agentes sociais para promover o uso industrial do território, como a concessão de incentivos fiscais e creditícios (convênios com o Indi, o BDMG e outras agências estatais) e a qualificação da mão de obra (parcerias com o Senai, a Fiemg, o Sinmec, a Faex etc.);

c) o planejamento contínuo do processo de industrialização local;

d) a divulgação das vantagens da localização industrial em Extrema junto ao empresariado;

e) a adoção de instrumentos próprios para captação de investimentos externos, como a doação de terrenos, a isenção de tributos municipais, a remissão de débitos e taxas ou o empréstimo de pessoal e de equipamentos às indústrias.

No tocante ao planejamento da industrialização local, verifica-se a opção tácita do executivo municipal em diversificar o parque industrial e a estrutura produtiva em Extrema, a partir de 1990. O objetivo imediato dos gestores públicos consistia em alavancar a arrecadação municipal, angariando o máximo possível de recursos para financiar as obras de infraestrutura, os serviços urbanos e a diversificação econômica em Extrema, até então uma cidade pequena semelhante a outras de seu contexto regional.

A implantação da estadunidense American National Can ${ }^{10}$, em 1996, representou um marco para a diversificação da origem dos capitais investidos no setor secundário, revelando a entrada de capitais estrangeiros em Extrema. Nos anos seguintes, grandes estabelecimentos nacionais e estrangeiros passaram a investir no município, conforme o Quadro 1. Com o crescimento industrial, o recolhimento de impostos multiplicou-se no município.

De acordo com Carvalho (2018), não existem gêneros industriais que sejam preteridos, a priori, pela administração local em suas políticas industriais; na atualidade, o que se busca é o equilíbrio entre os gêneros da indústria e outros setores, como os centros de distribuição e os e-commerces, na absorção da mão de obra local. A ênfase na diferenciação da base produtiva visa salvaguardar o mercado de trabalho, a economia e a capacidade tributária do município de eventuais crises sobre gêneros industriais ou setores econômicos específicos.

A Secretaria de Desenvolvimento Econômico e Empreendedorismo divulga, de maneira incisiva, as vantagens da localização industrial em Extrema, no meio empresarial. Os principais argumentos para sensibilizar os investidores

10 Unidade fabril adquirida pela Rexam do Brasil LTDA, em 2000; desde 2016, pertence à Ball do Brasil LTDA. 
são: a posição geográfica privilegiada do município no território nacional, com ênfase na proximidade à capital paulista e na infraestrutura logística favorável; a paisagem exuberante propiciada pela Serra da Mantiqueira, pelos fragmentos de matas e pelas cachoeiras; a presença de outras indústrias, muitas das quais de grande porte e líderes em seus campos de atuação; os programas de preservação do meio ambiente e a qualidade de vida, comprovada pelos bons índices socioeconômicos do município; o "espírito" acolhedor e tranquilo de cidade pequena etc. (CARVALHO, 2018).

Os principais instrumentos utilizados pela prefeitura para atrair novas unidades fabris a Extrema são a doação de terrenos, a isenção de tributos municipais, a remissão de débitos ou de taxas e o empréstimo de pessoal ou de equipamentos para a prestação de serviços esporádicos e específicos nas indústrias.

A doação de terrenos, principalmente em distritos industriais, foi o principal expediente utilizado para atrair grandes indústrias a Extrema, até meados dos anos 2000, quando se esgotaram as maiores reservas de imóveis passíveis de negociação. De acordo com Carvalho (2018), as glebas atualmente disponíveis comportam apenas empreendimentos industriais de pequeno porte.

A isenção dos tributos municipais pode ser total ou parcial; incidir sobre um ou mais tributos, e beneficiar a indústria ou as empresas que lhe prestam serviços. De acordo com o Código Tributário de Extrema - Lei Municipal $n^{\circ}$ 003/2001 - os tributos municipais abrangem: os impostos, como o Imposto Predial e Territorial Urbano (IPTU), o Imposto de Transmissão Sobre Bens Imóveis por Ato Oneroso Intervivos e o Imposto Sobre Serviços de Qualquer Natureza (ISS); as taxas, como as Taxas de Serviços Urbanos, as Taxas de Licença, as Taxas de Expediente e Emulamentos, as Taxas de Serviços Diversos e as Taxas de Recolhimento de Entulhos e Resíduos Industriais e Comerciais de Caráter Doméstico; as contribuições de melhoria (PREFEITURA MUNICIPAL DE EXTREMA, 2001).

A remissão de débitos e taxas consiste na quitação de dívidas pendentes das indústrias junto ao Poder Público local; enquanto o empréstimo de equipamentos do patrimônio municipal ou de pessoal do quadro de funcionários visa à realização de obras específicas - como a pavimentação ou a terraplenagem - nas indústrias por prazo pré-fixado.

Ainda que não tenham o mesmo impacto que os incentivos estaduais, os benefícios municipais também contribuem para a desoneração do processo produtivo e, consequentemente, para ampliar a reprodução dos capitais da indústria. 
Nos dias atuais, inexiste uma política industrial que discipline, de maneira global, os tipos de indústrias, os critérios utilizados para a concessão dos incentivos locais ou as contrapartidas exigidas das empresas que pleiteiam os benefícios da Prefeitura Municipal de Extrema (CARVALHO, 2018). Os trâmites para a instalação de novos empreendimentos estão centralizados no executivo municipal, mais precisamente na Secretaria de Desenvolvimento Econômico e Empreendedorismo, na Assessoria Jurídica e no Gabinete do Prefeito, que negociam, caso a caso, a concessão dos incentivos às indústrias (CARVALHO, 2018). Os incentivos fiscais concedidos atualmente pelo município são a isenção do IPTU e do ISS por cinco anos, renováveis por igual período (PREFEITURA MUNICIPAL DE EXTREMA, 2017b).

Vale lembrar que as grandes indústrias são mantidas por recursos de origem exógena, de modo que o município encontra-se, de certa forma, vulnerável às oscilações de ordem político-econômica que resultem na redução ou na cessão dos investimentos externos na economia local. Carvalho (2018) aponta que, recentemente, alguns empresários estavam inclinados a transferir a produção de Extrema para o Paraguai, atraídos pelos baixos salários (menores do que no município), pela fragilidade da organização sindical e pelas políticas de desoneração fiscal daquele país.

Nesse sentido, a mesma guerra fiscal dos lugares, cujos efeitos contribuíram decisivamente para o crescimento industrial, econômico e urbano do município nas últimas décadas, pode estimular a migração dos estabelecimentos em Extrema para lugares que ofereçam condições mais atrativas para a reprodução do capital da indústria, reduzindo as oportunidades de emprego, a geração de renda e o recolhimento de impostos no município.

A iniciativa de elevar o turismo à segunda economia do município exprime justamente a preocupação dos gestores públicos em criar alternativas para a promoção do desenvolvimento local em bases endógenas, de modo a contrabalancear a dependência e a vulnerabilidade da economia do município, respectivamente, aos recursos e às ingerências externas.

Dessa forma, a mesma percepção do grupo político sobre as tendências da localização industrial, que contribuiu para a definição e a consecução do modelo de industrialização adotado em Extrema, em meados da década de 1990, permite à atual administração reconhecer as fragilidades e os limites do crescimento industrial e econômico, baseado em capitais externos, no atual cenário das relações industriais e econômicas no Brasil e no mundo. 


\section{Ações das instituições privadas ligadas à indústria}

Além da administração estadual e municipal, o empresariado também se mobiliza para instrumentalizar o território com infraestruturas e normas propícias ao desenvolvimento industrial, tendo em vista a redução dos custos de produção e a competitividade das indústrias nos mercados nacional ou global.

A Fiemg é a principal instituição representativa das indústrias em âmbito estadual, defendendo os interesses de suas coligadas nacionalmente ou prestando consultoria sobre aspectos relevantes para a produção industrial, como o acesso ao crédito e às linhas de financiamento, os tributos, as normas ambientais e as relações trabalhistas.

Em Extrema, os programas e os serviços prestados pela Fiemg são coordenados pelo Sinmec, sindicato patronal que representa as indústrias metalúrgicas, mecânicas e de material elétrico. De acordo com Cesarino (2018), o sindicato "[...] apoia, através da Fiemg, todas as necessidades das empresas, como a formação de mão de obra (Senai), apoio jurídico em tributos, trabalhista e meio ambiente, além de consultorias e pesquisa".

Desde a fundação em 1990, o Sinmec é muito atuante em seu domínio territorial e participa ativamente do modelo de industrialização implantado em Extrema, na qualidade de articulador entre o Poder Público estadual e municipal e as empresas. O campo de atuação do Sinmec envolve: a) a representação dos interesses patronais nas convenções coletivas com os trabalhadores; b) a administração do Balcão de Empregos, agência que registra e divulga as oportunidades de trabalho local e regionalmente; c) a interlocução com potenciais investidores do setor secundário, com o intuito de elucidar as vantagens e os obstáculos da localização industrial em Camanducaia, Cambuí, Extrema e Itapeva.

Em resumo, o Sinmec centraliza as demandas e os interesses classistas, defendendo-os junto ao Poder Público e a outras entidades privadas com a finalidade de tornar o território mais propício à produção industrial. Por esses motivos, é possível qualificá-lo como um dos agentes sociais diretamente envolvidos no crescimento industrial e econômico em Extrema.

\section{CONSIDERAÇÕES FINAIS}

A compreensão das mudanças recentes na repartição geográfica das unidades produtivas demanda a abordagem multiescalar dos eventos que condicionam a dinâmica locacional das indústrias nas diferentes escalas geográficas. 
Na escala global, a internacionalização do capital e da produção, a reestruturação produtiva das empresas e a globalização acentuaram a disjunção espacial do processo produtivo e possibilitaram a conformação de circuitos espaciais de produção e de círculos de cooperação, de extensão global, coordenados pelas transnacionais.

Simultaneamente, a desconcentração industrial e a guerra fiscal dos lugares integraram novas áreas ao processo produtivo, modificando o padrão regional de distribuição das indústrias no Brasil. Tais processos aprofundaram a divisão territorial do trabalho da indústria no sentido de algumas cidades pequenas brasileiras, tradicionalmente concebidas como últimos elos na transição urbano-rural e associadas às atividades agrícolas.

Nesse sentido, a implantação de grandes indústrias nacionais e internacionais em Extrema, nas últimas décadas, revela a complexidade crescente do espaço industrial e das relações industriais no Brasil. De modo geral, os grandes investimentos da indústria foram motivados pela localização estratégica da cidade, às margens da Rodovia Fernão Dias (BR 381), pelos baixos salários e pelos esforços de diversos agentes sociais - Governo de Minas Gerais, Prefeitura Municipal de Extrema, sindicato patronal etc. - na criação de condições propícias para o desenvolvimento industrial no município.

Na prática, esses fatores locacionais contribuem para a reprodução ampliada dos capitais da indústria, porque reduzem os custos das fases mais padronizadas da produção, como a transformação e a montagem industrial. Desse modo, a emergência de Extrema como lócus da produção propriamente dita de grandes indústrias revela a capacidade dos agentes hegemônicos de proceder ao uso corporativo do território, no atual cenário da organização e das relações industriais.

Assim sendo, a emergência de algumas cidades pequenas, como Extrema, à condição de destinos prioritários para os grandes investimentos na indústria merece destaque na investigação científica porque contraria os estudos clássi$\cos$ em Geografia Industrial que conferiam às metrópoles e às cidades grandes e, posteriormente, a algumas cidades médias, a supremacia na captação desses recursos. Além disso, rompe-se com a noção de que a estrutura produtiva e a dinâmica socioespacial das cidades pequenas se baseiam fundamentalmente nas atividades agrícolas, de modo que tais lugares não contariam com atributos capazes de atrair grandes investimentos da indústria, diferentes daqueles que mantêm agroindústrias. 


\section{REFERÊNCIAS}

AGÊNCIA DE PROMOÇÃO DE INVESTIMENTO E COMÉRCIO EXTERIOR DE MINAS GERAIS. O Indi. Belo Horizonte: Indi, 2018. Disponível em: $<$ http://www.indi.mg.gov.br/>. Acesso em: 7 jan. 2018.

\section{ASSEMBLEIA LEGISLATIVA DE MINAS GERAIS. Incentivos fiscais para} indústria, comércio e serviços. Belo Horizonte: ALMG, 2018. Disponível em: $<$ https://politicaspublicas.almg.gov.br/temas/incentivos_fiscais_industria_comercio_servicos/entenda/informacoes_gerais.html?tagNivel1=241\&tagAtual $=10504>$. Acesso em: 1 mar. 2018.

CARVALHO, A L de. Industrialização em Extrema. [jan. 2018]. Entrevistador: E. M. Oliveira. Extrema: Secretaria de Desenvolvimento Econômico e Empreendedorismo, Prefeitura Municipal de Extrema. 1 cassete sonoro (128 min).

CESARINO, S. Produção industrial em Extrema. [jan. 2018]. Entrevistador: E. M. Oliveira. Extrema: Sinmec. 1 e-mail.

CORREAA, R. L. As pequenas cidades na confluência do urbano e do rural. Geousp - Espaço e Tempo, São Paulo, n. 30, p. 5 - 12, 2011.

DULCI, O. S. Política e economia em Minas Gerais: um balanço dos anos 1990. In: In: SEMINÁRIO SOBRE A ECONOMIA MINEIRA, IX, 2000, Belo Horizonte. Anais... Belo Horizonte: Universidade Federal de Minas Gerais, 2000.

FRESCA, T. M. Em defesa dos estudos das cidades pequenas no ensino de geografia. Geografia, Londrina, v. 10, n. 1, p. 27 - 34, jan./jul. 2001.

HARVEY, D. A produção capitalista do espaço. São Paulo: Annablume, 2005.

INSTITUTO BRASILEIRO DE GEOGRAFIA E ESTATÍSTICA. Produto interno bruto dos municípios - Extrema. Rio de Janeiro: 2015. Disponível em: < https://www.ibge.gov.br/estatisticas-novoportal/economicas/contas-nacionais/ 9088-produto-interno-bruto-dos-municipios.html? $=\& \mathrm{t}=\mathrm{o}-\mathrm{que}-\mathrm{e}>$. Acesso em: 12 dez. 2016. 
MARQUES, A. F. do A. et al. Relações de trabalho nas indústrias em Extrema. [jan. 2018]. Entrevistador: E. M. Oliveira. Extrema: Stimeic. 1 cassete sonoro (120 min).

MENDES, A. Reestruturações locais como efeitos da globalização econômica: uma análise da estrutura produtiva mutante do polo têxtil de Americana - SP. 1997. 194 f. Tese (Doutorado em Geografia) - Instituto de Geociências e Ciências Exatas, Universidade Estadual Paulista Júlio de Mesquita Filho, Rio Claro, 1997.

MINAS GERAIS. Decreto n. 43.080, de 13 de dezembro de 2002. Aprova o Regulamento do Imposto sobre Operações Relativas à Circulação de Mercadorias e sobre Prestações de Serviços de Transporte Interestadual e Intermunicipal e de Comunicação. Assembleia Legislativa de Minas Gerais: Estado de Minas Gerais, Poder Executivo, Belo Horizonte, MG, 14 dez. 2002. Disponível em: $<$ https:/www.almg.gov.br/consulte/legislacao/completa/completa.html?tipo=DEC\&num=43080\&comp=\&ano=2002>. Acesso em: 15 jun. 2018.

MINISTÉRIO DO TRABALHO E DO EMPREGO. Relação anual de informações sociais - Extrema. Brasília: Programa de Disseminação das Estatísticas do Trabalho, 2016. Disponível em: $<$ http://pdet.mte.gov.br/rais?view=default $>$. Acesso em: 6 jan. 2018.

OLIVEIRA, L. E. G. de. Algumas considerações sobre a implantação de distritos industriais. Revista Brasileira de Geografia, Rio de Janeiro, v. 38, n. 4, p. 22 - 69, out./dez. 1976.

OLIVEIRA, E. M. A implantação de grandes indústrias de capitais nacionais e internacionais na cidade pequena de Extrema (MG): processos, fatores e agentes. 2018. 292 f. Tese (Doutorado em Geografia) - Instituto de Geociências e Ciências Exatas, Universidade Estadual Paulista Júlio de Mesquita Filho, Rio Claro, 2018.

PORCARO, R. M. Industrialização e tamanho urbano. Revista Brasileira de Geografia, Rio de Janeiro, v. 39, n. 1, p. 46 - 86, jan./mar. 1977. 
PREFEITURA MUNICIPAL DE EXTREMA. Lei Complementar n. 003, de 31 de dezembro de 2001. Institui o Código Tributário do município de Extrema e dá outras providências. Legislação: Prefeitura Municipal de Extrema, Extrema, dez. 2001. Disponível em: < http://legislador.diretriznet.com.br:8080/legisladorweb.asp?WCI=LeiConsulta>. Acesso em: 14 abr. 2018.

. Cadastro de empresas ativas. Extrema: Secretaria de Planejamento, Orçamento e Gestão, 2017a. 1 e-mail.

. Extrema, uma cidade preparada e projetada para o futuro. Extrema: Prefeitura Municipal de Extrema, 2017 b.

SECRETARIA DE ESTADO DE FAZENDA DE MINAS GERAIS. Consulta pública ao cadastro de contribuintes do ICMS - Sintegra. Belo Horizonte: SEF-MG, 2018. Disponível em: < http://www.fazenda.mg.gov.br/empresas/cadastro/consultapublica.htm>. Acesso em: 2 jan. 2018.

SELINGARDI-SAMPAIO, S. Indústria e território em São Paulo. A estruturação do Multicomplexo Territorial Industrial Paulista: 1950 - 2005. Campinas: Alínea, 2009.

SERVIÇO BRASILEIRO DE APOIO ÀS MICRO E PEQUENAS EMPRESAS. Anuário do trabalho na micro e pequena empresa - 2013. Brasília: Sebrae, 2013.

SINDICATO DAS INDÚSTRIAS METALÚRGICAS E MECÂNICAS E DE MATERIAIS ELÉTRICOS DE CAMBUÍ, CAMANDUCAIA, EXTREMA E ITAPEVA. Relação de indústrias instaladas na microrregião (Extrema, Itapeva, Camanducaia e Cambuí) - 2015/2016. Extrema: Sinmec, 2016.

SPOSITO, E. S.; SANTOS, L. B. O capitalismo industrial e as multinacionais brasileiras. São Paulo: Outras Expressões, 2012.

SPOSITO, E. S.; SILVA, P. F. J. da. Cidades pequenas: perspectivas teóricas e transformações socioespaciais. Jundiaí: Paco Editorial, 2013. 